\title{
The Effectiveness of Management Practice in the Market of Socially Important Services
}

\author{
E. M. Razumovskaya ${ }^{1}$, N. Kutsevol ${ }^{1}$, Michael Popov $^{1}$ Timur Mishakin $^{1}$, L. Leto ${ }^{1} \&$ Veronika Tsalikova ${ }^{1}$ \\ ${ }^{1}$ Kazan (Volga Region) Federal University, Russian Federation \\ Correspondence: E. M. Razumovskaya, Kremliovskaya str. 18, Kazan, 420008, Russian Federation. E-mail: \\ science-kfu@mail.ru
}

Received: June 1, 2014 Accepted: July 15, 2014 Online Published: September 28, 2014

doi:10.5539/ass.v10n20p118 URL: http://dx.doi.org/10.5539/ass.v10n20p118

\begin{abstract}
The management system of provision of socially important services is not good traditionally in any country. Problems are objective regularities of functioning of this sector, losing sight the objective laws in interaction between consumers and producers and the established practice of management in the market of socially significant services. This article discusses the patterns of management practice that must be taken in attention so the point of view of achieving maximum efficiency in the market of socially significant services. Midpoint in analysis becomes the consumer behavior in the market of socially important services; motives for his behavior and management practice of organizations which operating in this market. The target program which developed by the state don't tackle the real problems of this sector of the economy. These programs set performance criteria that don't reflect customer's requirements, and consequently, the sector of socially important services will remain ineffective in the eyes of a key customer. The concept of an effectiveness of the system of supplying socially important services requires the consideration of social, professional and economic efficiency. However, economic efficiency as key criteria for organizations in the market of socially important services cannot be exclusive and unique. Only professionalism in execution of key business processes can provide long-term economic efficiency in the organization. However, many organizations in the market of socially important services where the main goal become criteria of economic efficiency, provide only short-term economic effect, destroying themselves professionally and disappearing in the market.
\end{abstract}

Keywords: socially important services, social effect, social optimism and pessimism, social, professional and economic efficiency, duality of development strategies

\section{Introduction}

We all, in varying degrees, have in life with the need to consume intangible economic benefits, which providing socializing and regenerating effects, aimed at life sustaining of a person. Such services classical Economics are named as socially important services, people can not to refuse from consumption of them, but production and effective management system for the provision of these services have many questions. These questions may affect the decision of problems of production and consumption of socially important services, the governmental regulation of this economy sector and effectiveness of measures of state control, as well as problems of preferences in consumption of socially important services, which significantly depend from value system in society

The above-mentioned problems determine the tendencies of development of system of supplying socially important services that become an objective reality and explain why we have what we have (Safiullin, 2014).

The practice of the system of supplying socially important services is very interesting. Often, the behavior of the consumers and their motives respects set the system of relations in the market of socially significant services, which is identified as effective or not effective (Askhatova, 2014). We insist on that, as in any market, trends in the development of the system of supplying socially important services depend from the customer and his behavior, not from the system of target programs of development of those or other socially important industries, developed by the state which are isolated from reality behavior of the system and markets. Target program of development, in this case, should contribute the maximum value of the interests of consumers and their financial ability with the interests of the state in the development of human potential in country (Lavrov, 2000). It is in this real sense of the term "socially important" services. Moreover, assess the effectiveness of supplying socially 
important services outside the traditions of management will prevent reaching it.

\section{Discussion}

Now we consider the established traditions in the functioning of the system supplying socially important services, which substantially affect the ability to achieve efficiency and satisfaction of the consumer.

First, that comes into view is the system of expectations of the population about inefficient work of the subjects in the system of supplying socially important services. What would we say-about medical institutions, universities, public transport and others-negative assessment of their work in this market is obvious and every day. The question arises as to why the existing system of supplying socially important services obviously has a negative assessment, and how the negative expectations influence to development of this sector? There is wide range of previously developed economic theories (Lucas, 1991), (Buiter, 1981): we can begin with the theory of adaptive and rational expectations and continue by theory of psychological contracts in the behavior of people. (McInnis, 2008) But the most interesting in this question is such phenomena as social optimism and social pessimism as categories in philosophy and sociology, they clearly can explain why negative expectations will initiate similar negative trends in the development of the system of socially important services.

The social optimism is a positive perception by the individual and any social group of the life, prospects of social development as result of modification the social factors. Social pessimism, on the contrary, is negative perception of the individual or a social group of the prospects of social development as result of the new social factors. (Botasheva, 2002). We can say that the process of formation of social optimism is determined by three factors:

1) life experience,

2) system requirements of people,

3) conditions of development the system of supplying socially important services.

In turn, the experience of the people can be defined through indicators such as knowledge, values, and interests and other. Interweaving subjective (life experience, needs) and objective (state of the environment, situation, position the subject in the socio-economic and other) and determine the level of social optimism (Varlamova, 2014). If life experience and repeated dissatisfaction human needs in socially important services to match with the impossibility of achieving economic efficiency in the market of socially important services, development trends always will be negative.

We will stop on the review of the concept of efficiency in supplying socially important services. So, if we can speak about the effectiveness of the hospital, it will go on the degree of achievement of concrete results. So, the term "efficiency" in health care cannot be identified with the economic effectiveness. In health care, the economic effectiveness can be "zero" and even a "negative" result. (Trawick, 2001), (Connolly, 1999)

The effectiveness of the medical centre cannot be determined unambiguously. It is expedient to speak about the three types of efficiency: social, medical, economic, among which the priority is given to medical and social efficiency. Medical effectiveness is the degree of achievement of the medical result. In relation to one particular patient is improved health, restore lost functions of separate organs and systems. For medical center level and the industry, medical effectiveness can be measured by share of cured patients, reduction of cases of transfer of the disease into a chronic form etc.

Social efficiency is mapped to the degree of achievement of the social result. For particular patient is to return his to work and active life in society, satisfaction with medical care. At the level of the industry is the increase in life expectancy of the population, reduction of mortality and disability, the satisfaction of society system with medical care. But these are the indicators of human potential development in the country. (Bulnina, 2014)

Calculation of economic efficiency associated with the search for the most efficient use of available resources. This measure is necessary in assessing the performance of the health system as a whole, its separate subdivisions and structures, as well as economic justification for activity of medical centers. Feature, however, is that often care activities can be economically inefficient, but medical and social effect requires their conduct (Kundakchyan, 2014). For example, in case of medical care of older people with chronic diseases, with the obvious medical and social efficiency, the economic effect will be negative. With the use of modern medical preparations, intensive therapy and reanimation achieved medical and social effect-saved a person's life, however, people can become disabled and unable to work. In addition, the cost of medical care can exceed the expected economic results.

Thus, economic efficiency, in the social sector cannot be decisive. However, currently the normative documents 
do not contain precise instructions for selecting performance indicators in assessing of system of supplying socially important services. Each of the market sectors (education, health, housing etc.) are faced with their own choice in the achievement of performance indicators. However, none of the sectors cannot avoid the problem of choice and the optimal ratio: economic-social-professional efficiency in the market of supplying socially important services (Fakhrutdinova, 2014). And this is a priority for the government: to development of human potential and, consequently, in the long term to ensure long-term economic growth, or to talk about short term economic performance.

Also, speaking about tendencies of development organizations which work in the market of socially important services, it is worth mentioning the relationship between what is oriented organization in achieving efficiency and practice of management that the organization implements. So, if economic efficiency indicators become the main purpose for subject in the market of socially important services, as result market organizational culture, power distance, stiff domestic competition, standardization of the results of work will be an integral attributes of management practice. This practice of management for consumers of socially important services is not significant and does not lead to the expected results; moreover, much of the practice of management simply cannot complete the work in socially important organizations.

As a result, we can talk about the so-called duality strategies in development organizations in the market of socially important services that destroy the professionalism in organizations. It is an obvious reality that is happening in sectors of socially important services. Many researchers speak about it. (Aspers, 2011); (Sleiter, 2008).

Understanding the effectiveness of behavior in professional activities can, and will be determined by the criteria of effectiveness, which are developed on different levels of economic systems. Understanding employee-it must be some indicators, in understanding the higher level of the hierarchy in an organization-this will be other indicators, in understanding the Ministry level-this will be the third, fourth and others (Panasyuk, 2014). Paradox is that when forming the strategies of all these levels and we will speak "about General program (concept) of development...." in frame of professional activity. Hence, each following level in the organizational system will simply "agree" with the requirements from "above", developing "sparing" strategy of behavior which will be implemented (Kramin, 2014).

Duality of strategies, which we have already said, is so-called "own world" in the structure. And secondly, there is the subordination the structure to the needs of self-determination of people, but not professional interest. In our minds, "own world" in the structure and subordination structure are extreme forms of the same phenomenon. Here, the determining factor is the category of "power" and sources of power within the organization (Kutsevol, 2014)

A classic set of sources the power is often uninteresting in the simple enumeration. But at impossibility of self-determination itself through professionalism in the activity of the organization, the source of power as a competence ceases to be relevant. Formal position and access to corporate resources remain the dominant interest for employees. The organization itself, in this case, has all chances to be professionally destroyed. It can exist in time, but her main professional functions make it invisible for the potential client. That is why the sector of socially important services priori ineffective in the eyes of consumers. And they are absolutely right.

\section{Results}

Thus, we can assume that there is a system error in the practice of management organizations which supply socially important services. The system of supplying socially important services are operated on the basis not professional and social effectiveness, which will provide the development of the organization and the economic expediency of existence of the subject in the market of socially important services, and from short-term economic benefits.

A significant problem is to determine the effectiveness of socially important services in the eyes of consumers. Trends in determining the value of service in the eyes of consumers in more is dependent from influencing effect on the consumer. On the one hand, this is diversification of demand for socially important services that is identification of needs, the satisfaction of which is possible if the consumption of socially important services. Interesting is not so much their detailed definition as understanding how ambiguous can be set to meet these needs for each person. For some it becomes important functional component services, i.e. its main content and quality, for someone-subjective-psychological perception and atmosphere, for third-cultural and ethnic traditions and their observance, for many-price component services. Of course, that is not a complete list of requirements, which imposes serious requirements to the sector of socially important services in resource-limited settings. 
Therefore, the emergence of the private sector and public-private partnership becomes a certain way out of the situation. But if to approach to service delivery as the subject-to-subject relations, the problem will be stay. The higher the level of efficiency of rendering of services affects interpersonal interaction and tends to the subject-to-subject relations, the lower the efficiency of service provision depends on the technical characteristics of an organization, and to an even greater degree of professionalism and commitment of the staff of the organization. If such a relationship between the consumer and the service provider does not occur (as shown above), then the level of efficiency in the eyes of the consumer is not achieved.

Considering the consumer behavior in the market socially important services, we can allocate additional number of rules required for implementation in practice of management. From the management point of view, consumers of socially important services are not random, and it's usually the people that rarely changes to its consumer characteristics and preferences. This statement leads to the dynamics of the notion of "constant client". The client is understandable in its characteristics and possible behavior, but the classic definition of a "constant client" is not desirable, for example, in health and social welfare. Therefore, the policy of economic feasibility in the consolidation of the customer base for the company in this case is unacceptable.

\section{Summary}

Thus, the sector of socially important services is a completely different management practices from the point of view of its efficiency. The approach from the point of view exclusively necessity of state regulation of this sector often leaves unanswered the questions faced by the consumers of social services. The target program of development persistently builds reform policy sectors with no real impact on this process the key consumers of services. But such a one-sided examination of the functioning of the socially important sector will not lead to efficient solutions to problems in reality.

\section{References}

Askhatova, L., \& Bulnina, I. (2014). Quality-of-life (QOL) improvement as a strategic resource of sustainable social and economic development of a region. Life Science Journal, 11(6s), 354-357.

Aspers, P., \& Darr, A. (2011). Economic-sociological perspective on the anthropology. Economic sociology, 12(2), 301. Retrieved June 28, 2014, from http://ecsoc.hse.ru/issues/2011-12-2/index.html

Botasheva, S. (2002). Social optimism and pessimism as a philosophical antropogena. DisserCat. Retrieved June 28, 2014, from http://www.dissercat.com/content/sotsialnyi-optimizm-i-pessimizm-kak-filosofskaya-antro pogema\#ixzz342ufx5De

Buiter, W. H. (1980). In D. Currie, R. Nobay, \& D. L. Peel (Eds.), The role of economic policy after the new classical macroeconomics. Cambridge, Mass.: Macroeconomic Analysis: Essays in macroeconomics and econometrics.

Bulnina, I. (2014). Social optimism and pessimism as a philosophical antropogena. Life Science Journal, 11(6s), 469-472.

Connolly, S., \& Munro, A. (1999). Economics of the public sector (pp. 4-6). London: Prentice Hall Europe.

Fakhrutdinova, E., Severyanov, O., Shigabutdinov, A., \& Fakhrutdinov, R. (2014). The crisis of 1998 in Russia: Political intervention and its implications. Life Science Journal, 11(6s), 442-447.

Kramin, M., Safiullin, L., Kramin, T., \& Timiryasova, A. (2014). Drivers of economic growth and investment attractiveness of Russian regions. Life Science Journal, 11(6s), 526-530.

Kundakchyan, R., \& Zulfakarova, L. (2014). Current issues of optimal capital structure based on forecasting financial performance of the company. Life Science Journal, 11(6s), 368-371.

Kutsevol, N. (2014). Diagnostic characteristics of the organization in change management. Kazan: Center for Innovation Technologies.

Lavrov, A. M., Litwack, J., \& Sutherland, D. (2000). Fiscal Federalist Relations in Russia: A Case for Subnational Autonomy. Paris: Working Paper.

Lucas, R., \& Sargent, T. (1991). After Keynsian Macroeconomics. Rational Expectations and Econometric Practice, 301.

McInnis, K. J., \& Meyer, J. P. (2008, June). Psychological contracts and organizational commitment profiles: An examination of the employer-employee relationship. Posted presented at the annual convention of Canadian Psychology Association (CPA), Halifax, Nova Scotia. 
Panasyuk, M., Pudovik, E., \& Sabirova, M. (2014). Problems of labor market of modern Russia in conditions of stable economic growth. Life Science Journal 11(6s), 487-489.

Safiullin, L., Gafurov, I., Shaidullin, R., \& Safiullin, N. (2014). Socio-economic development of the region and its historical and cultural heritage. Life Science Journal, 11(6s), 400-404.

Sleiter, D. (2008). Taking market from economists. Economic sociology. Retrieved June 20, 2014, from http://ecsoc.hse.ru/issues/2008-9-2/index.html

Trawick, P. (2001). Successfully Governing the Commons: Principles of Social Organization in an Andean Irrigation System. Human Ecology, 1-26. http://dx.doi.org/10.1023/A:1007199304395

Varlamova, J., \& Larionova, N. (2014). Economic behavior of households: Cross-country comparison. Life Science Journal, 11(6s), 409-413.

\section{Copyrights}

Copyright for this article is retained by the author(s), with first publication rights granted to the journal.

This is an open-access article distributed under the terms and conditions of the Creative Commons Attribution license (http://creativecommons.org/licenses/by/3.0/). 